\title{
Modern Avrupa Tiyatrosundaki Dini ve Ruhani Boyutlar ${ }^{* *}$
}

\author{
Klaus Hoffmann
}

Tiyatro ile din arasındaki diyalogda teolojik bir tartışma ya da gerçeklik tartışması söz konusu değildir. Daha ziyade tiyatronun sanatsal ifade nitelikleri yardımıla gerçekleşen dolaylı bir diyalog bulunur. Tiyatro dinlerin şekillendirdiği ve ifade ettiği fikirleri, uzak görüşleri ve deneyimleri toplumun iletebileceği sembollerde, oyunlarda, ritüellerde (ayinlerde) ve gösterimlerde canlandırma gücüne sahiptir. Tiyatro sanata özgü olan deneyimlere olanak sağlar. Bu diyalogda bu deneyimlerin karşılıklı olarak algılanması ve "bizi mutlaka ilgilendiren" hususlar hakkında ortak iletişim söz konusudur (Tillich). Dinler arası bu diyalogu gerçekleştirmek geleceğin önemli bir görevidir. $\mathrm{Bu}$ tür bir diyalog duyularla algılamayı ve açıklığı gerektirir.

\section{Tiyatronun Başlangıcı (Von den Anfängen)}

Din ile tiyatro arasındaki gerilim dolu iliş̧kinin geçmişi ile ilgili küçük bir arasözü en başa koyuyorum: Tiyatro ve din Avrupa'da çıkıs itibariyle iki geçmişe ayrılır. Antik trajedi Yunan dini festivallerinden ve özellikle de Diyanozos festivallerinden doğmuştur ve birkaç binyıl sonra da Hristiyan Kilisesinin yumurta paskalyası ve Noel ayinlerinden dini oyun doğmuştur. Klasik Yunanistan'da gösterimler dini olaylar olarak görüldüğüinden, tiyatrolar kutsal yerlere inşa ediliyordu. Ve bugün bile tiyatronun oyun planlarında yer alan gerek Orest gerek Perslerde gerekse Medlerde olsun tannlannı oyunlarda gösteriyorlardı. Tanrilar öngörülemez, açıklanamaz ve akıl dışı olanı temsil ediyordu. Tannısal unsurların tiyatroya girişi bugünün aydınlanmış bilim toplumunun ve bilgi sahibi kuşağın birçok rejisörü için maruz kalınmak istenmeyen bir kışkırtma olurdu. Çoğu rejisör oyunlannda tanñlara yer vermez ya da tanrılan insan olarak küçültür ve açıklanabilir hale getirirdi. Bu payen tanrılara olan ilişki ilk bin yıllardaki Hıristiyanların tiyatroya karşı ikili bir tutum

\footnotetext{
** Bu makalenin Almanca'dan Türkçe'ye çevirisi Erdem Karabulut tarafından yapılmıştur.

- Alman Federal Oyun ve Tiyatro Üst Birliği Başkan, E-posta: hoffmann@bag-online.de
} 
takınmasına veya hatta tiyatroyu reddetmelerine yol açtı. Özellikle Roma Tiyatrosu ilk Huristiyanlanı zamanında ahlaki çöküşün merkeziydi, bu yüzden tiyatroya karşı çıkıs sadece dini temele değil, aynı zamanda ahlaki temele dayanyordu. Huristiyanlar tiyatroyu ancak 10. yüzyılın başlanında keşfettiler: Ortaçağın tiyatro kültürünü şekillendiren dini oyunlar ortaya çıktı. Tüm kültür ortaçağda Huristiyan öğelerin kuşaktan kuşağa aktarımiyla şekilleniyordu. Hıristiyanlık güzel sanatlarda olduğu gibi tiyatroda da neredeyse bir dışlanmışlık yaşıyordu. Başlangıçta halkın görsel etkilerinden dolayı kısa sürede benimsediği paskalya yumurtası oyunlan (İsa'mn yeniden dirilişini gösteren oyunlar) oynanyordu. Bu oyunlar o zamanki dindarlık uygulaması ile sıkı bir ilişki içindeydi. Daha sonra bu oyunları ıstırap oyunları takip etti (İsa'nın acılarını ve ölümünü temsil eden oyunlar). Bu temsiller özellikle kilise öğretisinin propagandasina hizmet ediyordu. Ancak kısa bir süre sonra kutsal hikâyelerin yanı sıra çeşitli parodi seçenekleri de denendi: eşek zengin bir cüppeye dönüştürülüyordu, tannnun annesi sarhoş bir bakire tarafından canlandırılıyordu, maskeli din adamları müstehcen şarkılar söylüyorlardı ve edepsiz hareketler yapıyorlardı. Daha sonlan bu parodileri yönetenler ve hiyerarși uizerine yapılan parodiler izledi. Mısra ve mısranın sahneye konulması "Güçlüleri tahttan kaldırur ve zayıflan oturtur". Ayinlerdeki tannyı öven methiyeler İncilin hükümdarlan eleştirmesine dönüştü. Başpiskoposun onuru azaltıldı, amirlerle roller değiştirildi. Korodaki erkek çocuklar en yüksek sandalyeleri, piskoposlar en alçak sandalyeleri alıyordu. Bu çocuklar başpiskoposu belli bir süre için kendi aralarından seçiyordu. Ortaçağ insanı parodileri kutsal metin gibi ciddiye alyyordu. Kültü bir yandan kabul ederken diğer yandan da eleştiriyordu. Ayinlerde dindar olabiliyordu ve resmi kültün eğlenceli parodileriyle bağdaşturabiliyordu. Yani dünyevi olanı onaylarken aynı zamanda dünyevi olana itiraz ediyor ve onu eleştiriyordu.

Tiyatronun köklerinin sadece kutsal olanda bulunmayacağı, aynı zamanda tiyatronun dinamik ve diyaloga dayalı bir kökeninin olduğu açıkça ortaya çıkmaktadır. Amerikalı tiyatro antropologu olan Schechner'e göre rituiel (etkili ve vurucu eylem olarak) ve eğlence (oyun ve şakanın ifadesi olarak) heyecan verici bir ilişki içine girmiştir. Hem tannyı yüceltmek ve inancı öğretmek için hem de insanı tiyatroya bağlamak maksadıyla onu eğlendirmek için oynanıyordu.

Parodiler düzenli kültün yoğun bir meydan okumasıydı, ayn zamanda da önemli bir görevi yerine getiriyordu: Parodiler dinsel olanın kendini yüceltme şeklinde ve ölü ritüellerle dondurarak kötüye kullanılmasını engelliyordu. 
Ancak sert şakalar törensel ve ciddi tarza göre giderek daha fazla yer aldığında ve insanların dünyevi ve eğlenceli işlerini anlatan pasajlar ağırlık kazandığında, bu oyunlar kilise kültürünün tebliğ ve öğretme amacının tamamen dışına çıkmıştı.

Dinsel içerikli oyunlar kilise dışına çıktığında, halkan görenekleri içine karıştı ve örneğin 14. yüzyılda gezgin vaizlerle ve din adamlan ile birlikte, cadı avcılanı ve Yahudi düşmanları ile birlikte Huristiyan kitle hareketleri şekline büründü. Istırap oyunlarında İsa vahşi bir şekilde işkence gördü ve çarmıha gerildi. Birinin saydığına göre İsa'da 5472 yara açıldı, artık onun acılarının sınırı kalmıştı. Vahşet ve şiddet deneyimleri pagan değer yargıları ile harmanlandı. Günah keçisi ritüeli gibi çarmuha germe ve duygusal kışkurtıcılık Yahudi düşmanlığının sık sık vahşi boyutlara kadar ulaşmasına yol açtu. (Gel Gibson'un "İsa'nın Acıları" adlı filmi bu tür kan ve acı mistisizmini sınır tanımadan gösterir.).

Avrupa'daki dinsel içerikli oyunun 500 yıllık geleneğinin sonunda bu oyunlar kilise ve resmi makamlarca yasaklandı.

Devlet ve toplumun din ilişkisi 18. yüzyılda değişti. Aydınlanma çağı akıl ve eğitimi öne çıkardı. Sanat ve bilim insanlan "kendi kusurlarının sonucu olan ehliyetsizlikten" kurtuldu. Zorunlu eğitim uygulaması insanlann okuma ve yazmayı öğrenmelerini sağladı. Okuma yazma bilmeyenler için açıklayıcı resimlere, fakir ve bilgisiz insanlar için İnçili açıklayan tekniklere artık ihtiyaç kalmadı. Bu bir kurtulma eylemiydi. Tiyatro artık kilisenin bir zeyili değildi ve artık dine alet edilemiyordu. Tiyatro binalan yapild. Tiyatro kendini dinden soyutladı.

Sanatın kiliseden kurtulması artan dünyevileşmesiyle özdeş değildir. Daha ziyade sanat ile din arasındaki ilişkinin yeniden belirlenmesi gerçekleşti. Sanatın özerkleşmesi dinden uzaklaşma anlamına gelmez, bilakis dini müesseselerinin doğrudan kontrolünde bulunan belirli yaşam alanlarının kendini dinden soyutlaştırması anlamına gelir. Bu durum dini uygulamalann fakirleşmesine ve körelmesine yol açmak zorunda değildir, tam aksine bir sonuç doğurur. Özerklik iki anlama gelen bir kurtulma demektir: Bağlardan kurtulma ve dünyaya yeni bakış açilarına doğru yönelme. Sanat üretiminde, sanatı yaşamada ve algılamada ve din içerisinde inancını yaşamada bir özgünlük meydana geldi. Sanat olanak bireylerin dini kendilerinin yorumlamalan için teşvik edebilen mesafeli yaşantılara olanak sağlar. Sanat çok sayıda yorum yapmaya imkân sağladığı gibi dini yorumlar yapmanın kapısını da aralar.

Gotthold Ephraim Lessing 1779 yllında dini hoşgörü üzerine "Nathan der Weise" (Bilge Nathan) adlı dramını yayımladı. Bu dramın odak noktasında Giovanni Boccaccio'nun 
„Decamerone“ adlı hikâyeler koleksiyonunda da yer alan bir yüzük kıssası bulunur. Yüzük kıssası aydınlanma çağının hoşgörü fikrini yansıtan bir anahtar metindir. Buna göre tannı her üç büyük dini de (Yahudilik, Hıristiyanlık ve İslam) aynı ölçüde sevmektedir.

Sultan Selehaddin Yahudi Nathan'a tek tanrilı üç dinden hangisini en doğru bulduğunu sorar. Nathan bu soruya kısas anlatarak cevap verir. Adamın birinin, taşıyanı tanrı ve insanlar önünde hoş biri yapma özelliğine sahip bir yüzüğü vardır. Bu yüzük birçok kưşak boyunca babadan kendisinin en çok sevdiği oğluna geçer. Ancak öyle bir an gelir ki baba üç oğlu arasında bir seçim yapamaz, bu yüzden yüzüğün iki kopyasını yaptunr ve her bir oğluna yüzüğünün gerçek olduğuna dair güvence verir. Baba öldükten sonra oğullan hangi yüzüğün gerçek olduğunun ortaya çıkması için mahkemeye başvururlar. Hâkim hangi yüzüğün gerçek olduğunu bulamaz. Üç kardeşe gerçek yüzüğün taşıyanı tüm insanlar nezdinde sevilen bir insan haline getireceği şeklindeki özelliğini hatırlatır. Eğer bu husus kardeşlerinden hiçbirinde gerçekleşmezse, bu ancak gerçek yüzüğün kaybolduğu anlamma gelecektir. $O$ zaman herkes insanların sevgisini kazanmak için çaba harcamalıdır. Bunu başaran kişi gerçek yüzüğün sahibidir. Bu kısas çok sayıda yoruma neden olmuştur.

1. Tann üç dini de aynı ölçüde sevmektedir.

2. Tann tüm insanlarca kabul edilen ve sayılan ve tüm insanlan birleştiren dini en çok sevmektedir.

3. Gerçek doğurduğu etkisinden anlaşılabilir. Aym şey dinler için de geçerlidir.

4. Aslında üç dine ayrlan tek bir din vardır. Yüzük kısasındaki hâkim tek bir tanrryı tanımaktadır ve üç büyük dini güçlü bir birlik haline getirmek lazımdır.

Fakat sürekli olarak müşahede ettiğimiz gibi, bu yorumlardan hiçbiri genel bir kabul görmemiştir. Buna rağmen Lessing'in hoşgörü çağrısı üzerinde her zaman için düşünmeye değerdir.

Friedrich Schiller tiyatronun yeni görevlerini şöyle suralar: Ahlaki kurum ve pratik bilgelik okulu, toplumsal-siyasi kurum ve aydınlanma çağının bir aracı, estetik kurunı. Bunlar Alman tiyatrosunda izlerini bugüne kadar hissettiren özelliklerdir.

\section{Tiyatro ve Kilisenin 20. Yüzyılda Birbirine Yakınlaşması}

Dinsel oyun geleneğinin bazı kalıntılara günümüz seküler kültüründe rastlamak mümkündür. Ancak bu kalıntılar ilke olarak büyü bilincinin eksikliğiyle farklılık gösterir. Obèrammergau'daki ıstırap oyunlannın geç ortaçağ kitle etkinlikleriyle ilgisi yoktur. Veba 
salgınına maruz kalınmadığı için her on yılda bir tüm köy halkı ile birlikte oynama şeldindeki 17. yüzyıldaki veba salgınları surasında tertip edilen adaklara kadar uzanan bu isturap oyunlarının bu kadar serbestçe yapılmadığını güncel bir tartışma ortaya koyar. Rejisör sahneler karanlıkta tiyatro bakımından daha etkili bir şekilde 1şıklandırılacağı için, İsa'nın İncil'deki aktarıma göre teşhirinin ve çarmı gerildiğinin gösterildiği oyunları öğleden sonra yerine akşamleyin oynatmak istediğinde, buna izin verilip verilmeyeceği konusunda hararetli bir tartışma bașladı. Fakat tiyatro tarafı ağır bastı. Bunlar Avrupa tiyatro tarihinin estetik eğilimine uygun olan sanatsal etkinliklerdi.

20. yüzyılın başlannda gençlik hareketi ve reform pedagojisi kapsamında kiliselerde amatör oyunlar yeniden canland. Gizemli oyunlara, ölü danslanna ve halk oyunlanna geri dönüldü. Liturya ilgisi de ulusal duyguların ve inancın azalmaya yüz tuttuğu gösterileri şekillendirdi. Mesaj verilmesi ve iletilmesi önem kazand. Dinsel oyun, diktatör ve terörist ulusal sosyalizmde kilise cemaatleri içerisinde ibadet olarak yapılan bir oyun olarak varlığını sürdürdü.

Amatör oyunlar ikinci dünya savaşından sonra 1933 yılının öncesindeki uygulamaya dayanuyordu. O zamanki profesyonel tiyatro biçimleri kullanılarak dini öğelerden arındırılmış yeni oyun biçimleri ortaya çıkmasına rağmen mesaj ileten oyunlar devam etti. Hıristiyan inancının bilgileri yemiden anlaşılabiliyor ve daha iyi bir dünyanın deneyimlenmesi gerekiyordu. Geleneksel amatör oyundan amatör tiyatroya bir geçiş yaşandı. 60'lı ve 70'li yıllarda tiyatro alanındaki değişimler burada etkisini gösterdi. Metinler serbest bir şekilde öznel olarak ve toplulukla birlikte ele alındı. Deney aşkı ve kendini gerçekleştirme önemli itici güçlerdi. Mesaj ileten eski oyunlar farklılaştı. O zamanki tiyatro hareketleriyle ve yaratıcılığın patlaması ile teşvik edilerek ve cesaretlendirilerek İncil metinleriyle kişisel ve öznel yüzleşmeye, doğaçlamaya oyuncu ile izleyici arasındaki etkileşim sürecine özel bir rol biçilmeye bağlandı. Sorular tiyatroda cevaplardan daha önemli hale geldi. Bundan da bugün kabul edilen İncil metinlerinin ve kişisel Hıristiyan varlığının keşfi uygulaması olan İncil dramı doğdu. Kişisel tecrübeleri oyun ve oyunla etkileşim yardımıla İncil'deki kişilerde ve hikâyelerde bulunan tecrübelerle bağlantılı hale getiren, tecrübelere ve kontrole yönelik grup içi bir yöntem doğdu. Yeni canlı karşılaşmalara ulaşmak ve duygusal klişelerden kurtulmak için kişisel tecrïbelerin başkalarının tecrübeleriyle yüzleşmesi gerekiyordu. İncil metinlerindeki yaşama hazzı uyandıran kurtarma potansiyelinin keşfi söz konusuydu. Gençlerin ve çocuklann Noel ve kreş oyunlan, dini eğitim içerikli temsiller ve kilise ayinin liturya kısımlan başanlı bir şekilde varlığım sürdürmüștür. 
İkinci Dünya Savaşından (1945) sonra profesyonel tiyatroda Thornton Wilder veya Reinhold Schneider ve diğerlerinin kilise tiyatrosu alanındaki oyunlan yardımıla savaşlarda zarar gören Hıristiyan değerlerini yeniden iletme çabaları oldu. Ancak bu çabalar bir sonuç vermedi. 70'li yllarda Hochhut'un papanın Yahudi soykurmm sırasinda tutumuyla ilgili "Stellvertreter (Temsilci)" adlı eseriyle kilise ile tiyatro arasında kritik bir diyalog başladı. Yerleşik kiliseye karşı bir isyan olan reformasyon Forte ve Osborne tarafindan Müntzer ve Luther'i konu alan oyunlarında canlandirldi.

Bu yillarda hastalıklı bir toplumu terapi ve metafizik törenleriyle iyileştirmek amacıyla cadde ve Pazar yerlerinde, salonlarda ve kiliselerde gösteri yapan tiyatro grupları ortaya çıktı. Bu gruplar savaşı ve yaşama düşman olan tüm güçleri reddettiler. Kukla tiyatrosu (Bread and Puppet Theatre) İncil'den alınan hikâyeleri işlediler, kukla ve büyük figürlerle Ahdi Atik'teki peygamberlerin sembolik hareketlerini anumsatan oyunlar geliştirdiler (Buch der Könige (Krallarn Kitabı), Schrei des Volkes nach Speisung (Halkın Yemek Çığlı̆̆g), Die 14 Stationen des Kreuzes (Haçın 14 İstasyonu)). Ritim, ritüel ve beden tiyatroda yeniden keşfedildi olay olarak daha az tiyatro oyunu sahnelendi. Canlı tiyatroda (Living theatre) doğrudan hayat üzerinde etki doğuran ritüel tiyatro doğdu. İzleyici ile oyuncu arasındaki mesafe ortadan kaldınlacak ve „unio mystica" (tek ruh) ortaya çıkacaktı. Örneğin "Şimdiki Cennet (Paradise Now)" adlı oyunda izleyiciler doğaçlamayla oyunun dokusu içine dahil ediliyor ve bir sahnede coşkulu bir kurtulma içine sürükleniyor ve tarz, meditasyon ve şarkılar izleniyordu.

Canl tiyatroyu izleyenler acemi askerler gibi ayn bedensel hareketleri yaparak dini alı̧̧urmaları askeri bir hapishanede sahneye koyduklarnnda, artuk bu temsilden öteye geçerek ritüele benzeyen hareketlerin icra edilmesi şeklini almışı. Böylece tiyatronun etkinlik arayışı içerisinde ritüelin etkinliğini keşfettiler. Arțk izleyici ve oyuncuya göre yapılan ikili bir ayrum olmayan ortak yaşantılan yarattılar. İzleyici oyuncu olacak ve estetik uzaklığın bırakacaktı. $\mathrm{Bu}$, özellikle varlı̆a ilişkin temel sorunların söz konusu olması halinde iyici belirginleşmiştir.

\section{Bugünkü Tiyatro İle Din Arasındaki Yeni Karşılaşmalar (Neue Begegnungen von Theater und Religion heute)}

Son dönemlerde Alman sahnelerinde İncil'i, On Emri ve inancı konu alan çok sayıda oyunun sahnelendiğini görmekteyiz. İnanç ve inançla ilgili metinler etik ve rubi durum olarak temsil sanatlarında ifadesini bulmuştur. Dini deneyimler ve dini bilgi gönüllü ve dogmatik olmayan bir şekilde canlanmıştur. 
Bunlarda hem kendini gerçekleştirmenin hem de dinsellik ve ruhanilik olmadan var olmayı deneyen yaşamlarımıza yönelik bir eleştirinin söz konusu olduğu ruhaniliğe bir özlem bulunmakta mıdır? Modern ampirizm (deneycilik) kendimizi aşma ihtiyacımızı tatmin etmiyor mu? Duygu ve hisler tamamen soyut bir hal mi aldı? Sosyal bağlar yok mu oluyor, ben tek bir içerik haline mi geliyor ve kendini tek bir kıstas olarak $\mathrm{mı}$ açıklıyor? Max Frisch' in onyıllarca önce tespit ettiği gibi, Aydınlanma çağı sona mı erdi ve onun yerine "altın dana (das goldene Kalb)" mı geçti? Tiyatro toplum için günlük sorunlarımızdan ve çözülmemiş toplumsal sorunlardan dolayı anlam, yönelme ve değerler arayış içine girer. Şu soruların cevaplarını arayıs içinde miyiz?: "Toplumumuz fanatik inanç savaşlarının karşısına neyi koydu? Hoşgörü ve çok kültürlülük yeterli olur mu? Giderek tüm ütopyaların ve ideolojik anlamlandırma çabalarının ortadan kalkmasıyla metafizik değerlere olan arayışın yeniden artacağı izlenimine kapılıyor muyuz? “ Hemen hemen tedavi etme görevi gibi görünüyor.

Tiyatro burada da uygunmuş gibi gözüküyor, çünkü estetiği her zaman duyularla algılamayla ilgilidir. Bu estetik hareket sahalannı, motifleri ve süreçleri somutlaştırır ve bilincin artmasına katkı sağlayabilir. Estetik bu şekilde etik davranışın ve ahlaki hükümlerin gerekli bir şartını yaratabilir. Tiyatronun estetiği; hayat tarzları, biçimleri ve yerleşik alışkanlıkları irdelemek için deneme alanlan sunar. Artık bugün insanın kasvetli ve saçma boyutların ve kişilerin ve davranışlannın karmaşıklı̆̆nı göstermek söz konusu değildir, bilakis ampirik dünyevi boyut transandantal taleplerle aşılmalıdır. Burada kendini kanıtlamış inancı kabul etmeye dönmek mümkün değildir. Daha ziyade yeni bağlamlar ve gerçekler keşfetmek ve insanın varlı̆ğ üzerine derin sorular yöneltmek istenir.

Soru sormak ve arka planda sorular yöneltmek tiyatronun doğasında olan bir husustur. Tiyatro soru ve cevap döngüsünü verimli bir şekilde dengede tutabilir, bunu atabilir ve yeniden arayış içine girebilir, bunları bulabilir ve sorgulayabilir. Tiyatronun burada temel sorularımıza yakınlaşmakta ve bu şekilde dini canlı tutmada hayret uyandırıcı bir gücü vardır.

\section{Tiyatronun Bugün Dini ve Ruhani Boyutlara Yaklaşımunun Özellikle Üç Yolu Vardır:}

1- Yazarlar ve tiyatrocular Ahdi Atik ve Ahdi Cedit metinlerini kullandular. Bu metinlerde çarpıcı siyasi güncel konulan da keşfettiler.

Rus rejisör Moskova'da suç ve sorumluluk konusunu irdeleyerek ve liturya şarkıları ve Ortodoks kilise müziği koreografisiyle Kudüs'ün tahrip edilişini anlatan 'Jeremia'nun Ağıtları 
(Die Klagelieder des Jeremias)" adlı tiyatro oyununu yaratt. Bu temsil ayn zamanda olan Çeçen savaşı nedeniyle büyük bir ilgi gördü.

Romeo Castellucci İtalya'da "Uyku Müzesinden Yaratılı̧ (Genesis - from Museum of Sleep)" adlı büyük bir üç kanatlı tablo yarattı. Yaratılış öncesindeki kaosu, Auschwitz'i ve Kain'in kardeşini öldürmesi konulanını işledi. Oyun eski İbranice olarak yazılan Tevrat'tan alınan resitalle başlar. Sözler ses etkisi yaratır. Castellucci yaratılıştan sonra insanlığın yok etme güdüsünün nasıl geliştiğini gösterir. Çocuklar Auschwitz'i oynar. En yaşlı çocuk beyaz bir frak içinde sanı renkli Yahudi yıldızı ile oyuncak tren üzerinde sahneye çıkar. Trenin çıkardığı sesler toplama kampina işaret eder. Üçüncü resimde işlediği suçu boşu boşuna geriye döndürmeye çalışan korkak katil olarak Kain' in resmedildiği kardeş cinayeti gösterilir.

\section{Tiyatronun Kökenlerinin Arayıșı (Auf der Suche nach den Ursprüngen des Theaters)}

Tiyatro burada tiyatro arkeoloji yöntemleriyle çalışır, köklerini arar ve bu arayıșta ritüel, ayinsel ve dinsel köklere rastlar. İster ortaçă̆ gizem oyunlan olsun, ister antik dönemdeki pagan rituieller olsun, ister Şamanizm olsun araştırmalarda dini öğeleri yüzeye fırlatan gayzerlere (Staniewski'ye göre) rastlanı.

Polonyalı rejisör Wlodzimierz Staniewski (Gardzienice'li) tarihin derinliklerine iner. Apuleius'un pagan inancın Hıristiyanlukla karşılaşması ile ilgili metinlere göre yazdığı "Değişim (Metamorphosen)" adlı oyunda antik şarkı tekniklerini inceler ve bundan bedensel ifadenin dinamizmi ile bir ritüel geliştirir.

Jerzy Grotowski de "Kaynak Tiyatro (Theater der Quellen)" adlı eserinde farklı kültürlerin şarkılanyla denemeler yaptı ve sallanmalann beden ve ruh üzerindeki etkileri araştırdı. Sallanarak söylenen şarkılar hemen hemen tüm kültürlerde ritüellerle ilintilidir. Bir ritüelin icrası söz konusu olur. Peter Sellars (ABD), Lin-Hwaimin (Tayvan), Ga Sola (Vietnam) gibi diğer rejisörler de antik çağdan, Samanizm'den, Vudu inancından ve gizem oyunlarından gelen eski ritüelleri ararlar.

3. Sonsuzluk deneyimiyle yüzleşmede hayata ve anlama ilişkin sorunlara değinilerek dini sorunlar ele alınır. Belirliliğin ortadan kaldırılmasıyla ilgisi olan, ölümle yüzleşen ve sımırh deneyimleri gösteren tiyatro dini deneyimleri uyandırır ve kendinden geçmeye neden olur. İzleyici önemli bir unsur haline dönüşür.

Marina Abramovicz "Kutsal Thomas'in Dudaklan (Die Lippen des heiligen Thomas)" adI oyunda kristal bir bardağı kırar ve kendi göbeğine yıldız resmi çizer, sırtını kırbaçlar ve demir bloktan oluşan bir haç üzerine çıplak olarak uzanır. İzleyiciler 30 dakika sonra oyunun içine 
dâhil olarak oyunu sonlandırır. Abramovicz sanat icra etmenin ölüme ve acıya ilişkin sorular sormak anlamına geldiğini söyler. Abramovicz bu sunurlı deneyimleri izleyicilerle birlikte yaşamak istemiş ve eylemlerini günümüze aktarmıştur.

Huristiyanlıkta sıklıkla gözlenen tensel düşmanlığa rağmen şu hususların da kayda geçirilmesi gerekmektedir:Ölümle yaşamı yansıtan birçok kutsal metinde bedensellik, tensellik, şehvani zevkler ve meczup düşkünlük işlenir. Ahdi Atik hatta bu konuda başlı başına bir kitap, neşideler neşidesi ve aşk şiiridir. Tanrı sevgisi erotik fanteziler deneyimlenmezse soyut ve anlamsız olma tehlikesi ile karşı karşıya kalır. Tanrı sevgisi ile aşk deneyimi arasında ilişkiler vardır. Aşk risklidir ve her zaman incitme ve yaralama tehdidi oluşturur. Çarmıha gerilen İsa'mn gaddarca derisi yüzülen bedeni Hiristiyan sembollerinin merkezinde bulunur. Insanlar hemen hemen bütün dinlerde tanrnyı memnun etmek için bedenleriyle yeni bir ilişki kurmak isterler. Oruç tutmak, feragat ve seksüel kendinden geçmişlik bedenle bu şekilde ilişki kurmanın içerisinde yer alır. Kendi kendini kurbaçlama birçok dinde bilinen bir şeydir. Acı yoluyla kendi bedenini algılamanın yoğunluğu artırılır ve İsa'nın çektiği acılara ulaşılacağı düşünülür. Beden iyileşme arayışının aracı haline getirilir.

Kültürel sahnede 60'lı ve 70'li yıllarda "çok keskin bir dönüşüm" gerçekleşir.

Günümüzdeki sahne uygulamasında tiyatronun yaşama yakınlaşmak için sanat niteliğini desteklemek istediği gözlenir. Şekli öykü değil, ritim ve olay belirler ve yoğunluk veya kendinden geçmeye işaret eder. Performans sanatı uygulamalanna uygun olarak göstermelik olaylar yerine gerçek olaylar sahnelenir. Artaud'un oyuncunun salt oyunculuk yerine tüm bedeniyle ve varlığıyla sadece gösterileni bünyesinde toplaması gerektiği şeklindeki talebine uyarak gösterim değil, icra etme esas alınır. Gösteriler anlamı vurgulamaz, aksine doğrudan mevcut materyali ve bedenselliği vurgular. Olmak ve anlamın, işaret ve gösterilenin birlikte ele alınması önem kazanır. Bu mistik olarak da ifade edilebilecek bir deneyimdir. Aktörler ve izleyiciler bir durumda birbirine bağlıdır ve birlikte doğrudan deneyimlerde bulunurlar. Şu anın deneyimi ile günümüzün bilinci oluşturulur. Bunlar ritüele çok benzeyen hususlardır. Burada izleyicinin aktörlerin performansı üzerinde sürekli üretken bir geri besleme oluşturduğu çok eski bir estetik hassasiyet olmakla birlikte yeni bir hassasiyet gelişti.

Parodi, komedi ve delilik dinle karşılaşmada yeniden keşfedildi. İsa'nın palyaço olarak tasvirinin derin tarihi kökleri vardır. İsa'nun sanatta en eski temsillerinden biri eşek kafalı bir insan şeklinin çarmıha gerilişini gösterir. Bu vahşi bir parodi mi yoksa gizemli bir işaret midir? Yer altı mezarlan Hıristiyanlan belki de bunda saçma durumlarımn bir sembolünü görmüşlerdir. Bu Hıristiyanlar "İsa'nın içindeki deliler" olduklanını biliyorlardı, fakat tanının 
deliliğinin insanların bilgeliğinden daha bilge olduğunu iddia ediyorlardı. Isa palyaçonun hatlanını taşır. Otoriteleri makaraya alır, kurallarla dalga geçer ve sonuçta karikatür gibi çarmıha gerilmek üzere kral giysilerine bürünür. Palyaço her zaman acı çeken ve kırgın olan, ama hiçbir zaman umudunu yitirmeyen bir başkasını temsil eder. Palyaço her zaman hayatun ve yaratıcı olanın tarafında durur. Dünya kaygısıyla tahripkâr mevcut düzenlere karşı baş kaldınır. Bu durum dinsel hususlar için de geçerlidir. İtalyan yazar ve tiyatrocu Dario Fo İncil'deki hikâyeleri halkın perspektifinden ve seyahat eden oyuncu gözüyle anlattığında bu izi tekrar yakalar. Kendini ve halkı geleneksel ve resmi İsa hikâyelerinden kurtarır. İsa'yı kilisenin ihtişamı ve zenginliğiyle hiçbir zaman tatmin olamayan ezilenlerin mütevazı muzafferi olarak geri kazanmak ister. Dario Fo'nun İncil hikâyeleri dinin yönetme amacıyla yaptığı sömürüyü hicveden bir nitelik kazanır. Diğer Alman yazarlar da deliyi yeniden keşfeder: Tankred Dorst "Oklann Hikayesi (Die Geschichte der Pfeile)" adh oyununda delileri "Tanrınun uzayan parmaklarn" olarak görür. Peter Handke "Daha birbirimizi tanımadığımız an (Die Stunde, da wir nichts von einander wussten)" adlı oyununda deliye özel bir rol verir. Palyaço burada bize dünyayı başka bir gözle görme olanağı sağlayan deliden başka bir şey değildir. Bununla tiyatronun temel bir görevi dile getirilmiştir: Tiyatro yaşamı tanıdığımız şekliyle göstermemelidir, bilakis yaşamın dışına çıkan, diğer gerçekleri ve bağlamlan keşfetmemize olanak sağlayan deneyimleri kazanmamızı sağlamalıdır. $\mathrm{Bu}$ da tiyatro ile din arasında bir diyalog kurulmasını gerektirir.

\section{Estetik ve Dini Deneyim/ Lanetli Mekânlamn Sahnelenmesi (Ästhetik und Religiöse Erfahrung / Inszenierung Sakraler Räume)}

Tiyatro sadece tiyatro kapıları önünde değil, aynı zamanda kiliselerin içinde de yeniden oynanır. Ancak burada da sanatı daha önce kurtulduğu kült haline yeniden dönüștürmek söz konusu olmaz. Kültü (dini) sanat haline getirmek de söz konusu değildir. Karşllıklı özerkliğe dikkat edilir: dini tiyatrodan ziyade kilise ve tiyatronun gerçekliğinin bütün genişliğiyle karşlaştıklan, birbirlerini ilhak etmedikleri, ancak bir diyalog geliştirdikleri tiyatro mekânında icra edilen bir tiyatro söz konusudur. Çünkü birbirine anlatacaklanı çok şeyleri vardır. Kilise mekanı tanının kelamını beklediğim, yaşadığım ve hatırladığım bir yerdir. Kilise mekanı hatırlama ve kendini düşünme mekanıdır. Bu mekanda inancın deneyim geçmişi kuşaktan kuşağa aktarılmış ve vaftiz, evlilik ve ölüm gibi yaşam geçişleri ritüel olarak şekillendirilmiştir. Bir yaşam durumundan bir diğerine, günlük hayattan günlük hayatın parçası olmayana, günümüz geleneğinden gelecekte umulan şimdiki zamana geçişler biçim kazanmıştur. Kiliseye adımımı attığımda diğer bir "anlam alanındaki" bir eșiği geçerim. Bu anlam alanı günlük hayatın kesintiye uğradığı ve aşıldığı bir yerdir. 
Bu alan tiyatronun hareket sahası olarak dini gerçeklik düzeyinde kalır. Sanat daha önce hiç olmadığı kadar içerik kazanır. İki türlü anlam düzeyi karşımıza çıkar. İzleyiciler, tiyatronun estetik gerçekliğiyle dini gerçeklik olarak mekân konseptlerinin karşılaşmasında farklan ve kırılganlıklan deneyimler. Bu durum bu alandaki yaratıcılığı oluşturur ve alışılmış ve dini algılama örnekleri sorgulanır, çelişkiler ortaya çıkarılır ve sürtüşmeler kendini gösterir. Burada yeni anlam alanlan açılabilir. Diyalog başlayabilir. Kimileri bu yeni deneyimlerden kaçınır ve hatta yoğun bir şekilde bu deneyimlere karşı kendilerini savunurlarken, kimileri de bu yeni deneyimleri yaşamaya hazır olurlar ve "yabancı olan şeye" karşı kendilerini açarlar. Anlamlan öğrenme, iyileşme, huzur ve güvene ilişkin beklentiler incitmeler, deneyim örneklerinin yerleştirilmesi ve önceden verilen algılama şekilleriyle çatışır. Sanatın anarşik bir boyutu vardır, sanat sınırlanı ortadan kaldırır ve özgürleştirir. Sanat dogmalara ve hâkimiyet taleplerine karşı çıkar. Ne kült ne de tiyatro bize yorum yapmaya olanak vermeyecek şekilde alanlar açabilir. Kült ve tiyatro daha ziyade içi bizim tarafımızdan doldurulabilecek serbest alanlanı yaratmak zorundadır. Bizde yorumlama etkinliği oluşabilmelidir. Bir şeyler bizi ilgilendirmelidir. Ritüellerin kilisenin ritüeli andıran alanında icra edilmesi halinde, tiyatro ile din arasındaki diyalogun ne kadar zor olabilecğini şu örnek gösterir: Avusturyalı tiyatrocu George Tabori 1987 yılında Salzburg şenliğinde Franz Schmidt'in "Yedi Mühür Kitabı (Das Buch der sieben Siegel)" adlı oratoryosunu Kollegienkirche'de sergilemişti. Bu oratoryo tartışmalara yol açmakla kalmadı, oratoryonun iptaline ve sadece konser şeklinde bir gösterime izin veren bir skandala da imza attı. Oratoryo Johannes'in vahiylerini tanımlar. Yedi mühürlü kitap sadece kuzu tarafından açılabilir. Bir mühüün açılması doğal afetlere, savaşa, acılara ve insanlığın ölümüne ve yok olmasına yol açar. Ancak baş melek Mikail'in kötuiyü yenmesinden sonra yedi sur (İsrafil) zamanın sona erdiğini bildirir. Tanrı acılara bir son verir ve yeni bir gökyüzü ile yeni bir dünya oluşur. Tabori bugün yaşadığımız gibi Johannes'in bu varlığa ilişsin korku ve umutlarını günümüze taşımayı amaçlar, kıyameti bulmak ister ve birleştirici bir şekilde hareket eder. Kilise ağacı hareket ve seyir alanına dönüşür, aktörler ile izleyiciler arasındaki sınurlar geçirgen hale gelir, estetik mesafe azahr.

Aktörler alandaki bir iskele üstünde şölensel giysiler içinde etrafta asılı duran kuklalarla giderek saldurganlaşan bir iletişim kurarlar. Organlar ve bedenin uzuvları yere düşer ve saldırganlık insanlara sirayet eder. Bedeni öne çıkaran bir eylem ve cinsellik tahripkâr bir hal alır, sadist ritüeller oluşur. İnsanlar arası alanda yıkım ve savaş kutsal dünyanın ön cephesini kutsayan küçük konuşmalarla sürekli olarak kesintiye uğrar. Büyük deprem sırasında tırnaklar korkuyla bedenlere geçirilir. Aktörler kıyametin barış içinde bildirildikten sonra kendilerine ekmek uzatmak isteyen genç bir adamın üzerine çullanarak onu ve bedenini yerler. Bu sahne 
toplumsal şiddeti bir birey üzerine uygulayan bir kurban ritüelidir. Bu birey savaşı çıkaran kişi olarak öldürüllür ve daha sonra şifacı mertebesine yükseltilir. Bu, Issa'nın kendini insanlık için feda etmesini ve akşam yemeğini anımsatır. Kurban edilen genç adam sonunda ayağa kalkarak iskeleye çıkar. Acaba o İsa mı, yoksa yeni Âdem mi, yoksa Johannes mi, belki de şeytanın ta kendisidir. Yorum açıktır, buna hazır olan bir kişi için bir diğer yorum alanı açılır. Standart bir bakış açısı ve tek bir anlamlandırma reddedilir. Kızgınlık had safhaya çıkar, farklı düşünceler birbiri ile çatışır, pornografik gösteri suçlaması yapılır, üretken bir irdelemedir, bir diyalog gerçekleşmez.

\section{Tiyatronun Genel Görünüşü}

Avrupa'daki ve doğal olarak Almanya'daki toplumlar küreselleşme ve dünya çapındaki göç hareketleri sürecinde son 50 yil içinde değişmiştir. Bu toplumlar çok etnik kökenli ve kültürler arası bir boyut kazanmıştır. Almanya bu arada 19 milyon göçmene ev sahipliği yapmaktadır. En büyük grup Türkiye'den gelmiştir ve İslam dinine mensuptur. Alman toplumunun sadece Huristiyanlardan oluştuğunu iddia etmek artık mümkün değildir. Islam dini artık göz ardı edilemez. Tiyatro Almanya'daki bu çok kültürlülügü ve din çeşitliliğini nasıl ele alacaktır? Tiyatro henüz buna bir tepki göstermiş değildir. Çocukken Türkiye'den Almanya'ya gelen Feridun Zaimoğlu adlı bir yazar bu alanda bir istisna oluşturur. Çok defa oynanan "Kara Bakireler (Schwarze Jungfrauen)" adlı oyunu eleştirmenlerce en iyi Almanca oyun seçilmiş ve bu oyun kitleleri kendine çekmeyi başarmıştır. Burada oyunlar kültürler arası konulanı işlemesine rağmen göçmenler tiyatroda pek görülmediğinden Alman izleyiciler söz konusudur. Oyunun gösterimi Almanlann beyinlerindeki sadece evde oturan ve çocuklara bakan ve dünyadan haberi olmayan başörtülü uslu kadın imajım yerle bir etmiştir. Müslüman kadınlar sahnede Almanya'da yaşadıklan kültürrlerin kopukluğundan söz ederler, kendilerine şüpheyle yaklaşılmasına ve kendilerini dinlerinden ötürü sürekli olarak savunmak zorunda kalmalarına karşı çıkarlar. Kendilerini kızgınlıkla ve gururla, aym zamanda da birçok çelişkiyle ifade ederler.

Feridun Zaimoğlu Almanya'daki genç Müslüman kadınlarla görüşmeler yaparak hayat hikâyelerini monolog şeklinde kaleme almıştır. Bu görüşmelerin içeriğine dokunmamakla beraber utangaç ve üstü kapalı olmayan, tam aksine doğrudan, amiyane ve müstehcen olan kendi diline aktarmıştır. Genç kadınlar inançlanndan eminlerdir ve kimi İkiz Kulelerin yerle bir edilmesini doğru bularak, kimileri de Osama bin Ladin'i sevdiğini söyleyerek radikal ve siyasi açıdan kışkurtıcıdır. Nefret, saldırganlık, coşku ve aşk hasretini küstahça dile getirirler, açıkça "düzüșmeden” “ kabaran gögüülerden” söz ederler. Kadınlardan biri şöyle der: "Günde beş kez 
ibadet ediyorum. Ramazanda oruç tutuyorum. İnançlı bir Müslüman'ım. Ama inancıma zarar vermeyeceğini bildiğim için hala seks yapıyorum."

Yazar Feridun Zaimoğlu şöyle der: Müslüman kadınlar örtülü olsalar da Huristiyan geleneğe oranla bedenlerine karşı pervasız bir ilişkilerinin olması şaşırtıcıdır. Bedenine düş̧man olma İslamiyet'te çok büyük bir günahtır, ömür boyu bekâr kalma cehenneme gitmeyi gerektirir." Zaimoğlu seks ve İslamiyet'i birbirine bağlayarak bizden bazı şeyler talep eder. Yan belgesel bir oyunuyla ilgili olarak şöyle der: “ Aydınlanmaya karşı olan her şeye yıkıcı bir merak duyuyorum. Benim için anlayış, hoşgörü ya da empati o kadar önemli değildir. Aynı şekilde özellikle eskimiş tutumları göstermek beni artık ilgilendirmiyor. Benim asıl meselem bu insanları ahlaki olarak değerlendirmeden görünür hale getirmektir. Kötü çok iyi de olabilir."

Dinlerin tiyatrodaki uyumlaştuncı olmayan, aksine farklllıklanyla ve çok sesliliğiyle bir diyalog oluşturması heyecan verici deneyimleri ve birlikte yaşamamıza yardımcı olacak birçok bilgiyi de sağlayacaktır. 
1 


\title{
Religious and Spiritual Dimensions in Contemporary European Theatre
}

\author{
Klaus Hoffmann*
}

Im Dialog von Theater und Religion geht es nicht um einen theologischen Disput oder gar um einen Streit um die Wahrheit. Vielmehr ist es ein indirekter Dialog mittels der künstlerischen Ausdrucksqualitäten des Theaters. Theater hat die Kraft, Ideen, Visionen und Erfahrungen, die auch von den jeweiligen Religionen mitgestaltet und mitformuliert werden, lebendig werden zu lassen in gesellschaftlich vermittelbaren Symbolen, Spielen, Ritualen und Darstellungen. Es ermöghcht besondere, gerade der Kunst eignende Erfahrungen. Es geht in diesem Dialog um die gegenseitige Wahrnehmung dieser Erfahrungen und um die gemeinsame Kommunikation über das, „was uns unbedingt angeht." (Tillich). Diesen intereligiösen Dialog einzuüben ist eine wichtige Zukunftsaufgabe. Ein solcher Dialog setzt sinnliche Wahrnehmung und Offenheit voraus.

\section{Von den Anfängen}

An den Anfang stelle ich einen kleinen Exkurs ïber die Geschichte des spannungsreichen Verhältnisses von Religion und Theater : Theater und Religion teilen sich in Europa zwei Ursprungsgeschichten miteinander. Aus den griechischen Kultfesten, besonders den Dionysosfesten, entwickelte sich die antike Tragödie und eineinhalb Jahrtausende später aus den Oster- und Weihnachtsmessen der christlichen Kirche das geistliche Spiel. Im klassischen Griechenland wurden die Theater an den heiligen Stätten gebaut, weil die Aufführungen als religiöse Ereignisse gesehen wurden. . Und in den Stücken ließen sie ihre Götter auftreten, sei es in der Orestie, den Persern oder der Medea, die noch heute in den Spielplänen der Theater stehen. Die Götter repräsentieren das Unberechenbare, das Unerklärbare und Irrationale. Der Einbruch des Göttlichen wäre für viele heutige Regisseure einer aufgeklärten

\footnotetext{
* Vorsitzender Bundesarbeitgemeinschaft Spiel Und Theater, E-mail: hoffmann @bağ-online.de
} 
Wissensgesellschaft, einer Bescheidwisser-Generation eine Provokation, der sie sich nicht aussetzen wollen. Die meisten verzichten in ihren Inszenierungen auf die Götter oder machen sie menschlich klein, erklärbar. Die Christen in den ersten 1000 Jahren hat dieser Bezug auf heidnische Götter zu einer sehr ambivalenten Haltung oder sogar zur Ablehnung des Theaters geführt. Dieser Bezug zu den heidnischen Göttern, führte zu einer sehr ambivalenten Haltung oder sogar zur Ablehnung des Theaters durch die Christen in den ersten 1000 Jahren. Zur Zeit der ersten Christen war besonders das römische Theater ein Hort sittlichen Verfalls, so dass die Einwände gegen das Theater nicht nur von religiöser, sondern auch vor allem von moralischer Art waren. Erst mit Beginn des 10. Jahrhunderts entdeckten die Christen das Theater für sich: .es entwickelten sich die sog. Geistlichen Spiele, die die Theaterkultur des Mittelalters prägten. Im Mittelalter war die gesamte Kultur durch die christliche Überlieferung bestimmt. Wie in der Bildenden Kunst hatte das Christentum auch im Theater fast eine Exklusivität. Am Anfang standen die Osterspiele (Spiele von der Auferstehung des Herrn), die sich nicht zuletzt wegen ihrer Visuellen Eindrücklichkeit beim Volk bald durchsetzten. Sie stehen in einem engen Verhältnis zu damaligen Frömmigkeitspraxis. Später folgten die Passionsspiele (Spiele vom Leiden und Sterben Jesu Christi). Die Aufführungen dienten vor allem der Propaganda der Kirchenlehre. Bald erprobte man aber neben der Heilsgeschichte auch die vielfältigen Möglichkeiten der Parodie: der Esel wurde in reiches Ornat gewandet, die Mutter Gottes wurde von einer angetrunkenen Jungfrau gespielt, vermummte Geistliche sangen Zotenlieder, machten unzüchtige Bewegungen... Später folgten auch Parodien über die Obrigkeit, die Hierarchien. Der Vers und seine szenische Darstellung , Er stößt die Gewaltigen vom Thron und erhebt die Niedrigen. " , das Deposuit des Magnificat, (dem Lobgesang Gottes im Gottesdienst) wurde zur biblischen Herrscherkritik. Die bischöflichen Würden wurden relativiert, ein Rollentausch mit Vorgesetzten erfolgte. Die Chorknaben nahmen die obersten Stühle und die Stiftsherren die niedrigsten. Sie wählten sich den Bischof auf Zeit aus ihren eigenen Reihen. Der mittelalterliche Mensch konnte offenbar die Parodie wie den heiligen Text gleichzeitig ernstnehmen. Er akzeptierte den Kult , und er kritisierte den Kult. Er konnte fromm sein in der Messe und konnte es verbinden mit der fröhlichen Parodie des offiziellen Kults. Zustimmung zur Welt und zugleich Widerspruch und Kritik an Zuständen der Welt.

Hier wird auch deutlich, dass die Wurzeln des Theaters nicht nur im Heiligen zu finden sind, sondern Theater einen dynamischen, dialogischen Ursprung hat, wo nach Schechner, dem amerikanischen Theaterantropologen, Ritual ( als wirksame performative Aktion) und Unterhaltung (als Ausdruck von Spiel und Spaß) eine spannende Beziehung eingehen. Man 
spielt zur Ehre Gottes, belehrt und agitiert für den Glauben, aber man spielt auch zum Vergnügen der Menschen und zu seiner Unterhaltung, um ihn an das Theater binden zu können

Die Parodien waren eine massive Herausforderung des ordentlichen Kultgeschehens, aber sie hatten auch eine wichtige Aufgabe: Sie verhindern einen Missbrauch des Religiösen in Form von Selbstverherrlichung und Erstarren in tote Ritualisierungen.

Als aber der derbe Witz schließlich gegenüber dem feierlichen, ernsthaften Ton immer mehr Raum einnahm, die Passagen des weltlich lustvollen Treibens der Menschen überwogen, waren diese Spiele für die Kirchenkultur und ihre Verkündigungs- und Belehrungszwecke entgültig verloren..

Als die geistlichen Spiele dann aus den Kirchen ausgezogen waren, vermischten sie sich mit Volksbräuchen und nahmen z.B. im 14. Jahrhundert die christhchen Massenbewegungen auf, mit den herumziehenden Volkspredigern und Geislern, mit den Hexenverfolgern und den Judenhassern. In den Passionsspielen wurde Jesus brutal gefoltert und ans Kreuz geschlagen. 5472 Wunden wurden ihm zugefügt, hat einer gezählt, sein Leiden hatte keine Grenzen. Greuelund Gewalterfahrungen wurden mit heidnischen Vorstellungen vermengt. Eine Kreuzigung wie ein Sündenbockritual, eine emotionale Überhitzung, die nicht selten zu brutalen Judenprogromen führten. (Solche Blut- und Leidensmystik nimmt zuletzt der Film von Gel Gibson „Die Passion Christi“" ungehemmt auf.)

Am Ende der 500jährigen Tradition des Geistlichen Spiels in Europa stand dann das kirchliche und behördliche Verbot.

Im 18. Jahrhundert verändert sich das Verhältnis von Staat und Gesellschaft zur Religion.

Die Aufklärung setzt auf Vernunft und Bildung. Kunst und Wissenschaft verhalfen, die Menschen aus der „selbstverschuldeten Unmündigkeit“ zu entlassen. Schulpflicht vermittelte Lesen und Schreiben. Man brauchte nicht mehr die erklärenden Bilder für die Analphabeten, die Techniken der Biblia Pauperum, der Bibel der armen und Unwissenden. Es war ein Akt der Befreiung. Das Theater war nicht mehr Appendix der Kirche und konnte nicht mehr einfach für die Religion instrumentalisiert werden. Es schuf sich eigene Häuser .Das Theater emanzipierte sich von der Religion. 
Die Loslösung der Kunst von der Kirche ist nicht mit ihrer fortschreitenden Säkularisierung identisch. Vielmehr vollzieht sich eine Neubestimmung des Verhältnisses von Kunst und Religion. Autonomie der Kunst heißt da nicht einfach Verabschiedung und Verdrängung von Religion, sondern vielmehr die Emanzipation bestimmter Lebensbereiche aus der direkten Kontrolle der Institutionen der Religion. Das muss nicht zur Verarmung und Verkümmerung religiöser Praxis führen, im Gegenteil. Die Autonomie bedeutet auch eine Freisetzung in doppeltem Sinne: Befreiung von Bindungen und Befreiung zu neten Sichtweisen auf die Welt. Es vollzieht sich eine Individualisierung der Kunstproduktion, der Kunsterfahrung und Kunstwahrnehmung und ebenso eine Individualisierung der Glaubenserfahrungen in der Religiosität. Kunst lässt Distanzerfahrungen zu, die Individuen zu religiöser Selbstdeutung anregen können. Sie öffnet für eine Vielfalt von Deutungen, auch religiösen Deutungen.

1779 veröffentlichte Gotthold Ephraim Lessing sein Drama "Nathan der Weise", über die Religionstoleranz. Im Mittelpunkt steht da die Ringparabel, die sich bereits bei Giovanni Boccaccio in der Geschichtensammlung „Decamerone“ findet. Die Ringparabel ist ein Schlüsseltext der Aufklärung mit der Idee der Toleranz, dass Gott die drei Religionen (Judentum, Christentum und Islam) gleichermaßen liebe.

Der Sultan Saladin fragt den Juden Nathan, welche der drei monotheistischen Religionen er für die richtige die Wahre halte. Nathan antwortet mit einem Gleichnis. Ein Mann besitzt einen Ring, der über die Eigenschaft verfügt, seinen Träger „,vor Gott und den Menschen angenehm“ zu machen. Über viele Generationen hinweg wurde dieser Ring vom Vater an den Sohn vererbt, der ihm der liebste war. Doch nun möchte der Vater keinen seiner drei Söhne bevorzugen, deshalb lässt er zwei Duplikate von dem Ring anfertigen und versichert jedem, dass sein Ring der Echte sei. Nach dem Tod des Vaters ziehen die Söhne vor Gericht, um zu klären, welcher der Ringe der Echte sei. Der Richter sieht sich nicht in der Lage, das zu ermitteln. Er erinnert die drei Söhne daran, dass der echte Ring die Eigenschaft habe, den Träger bei allen anderen Menschen beliebt zu machen. Wenn dieser Effekt aber bei keinem eintrete, könne das nur bedeuten, dass der echte Ring verloren ging. Jedenfalls solle sich jeder darum bemühen, die Liebe seiner Mitmenschen zu verdienen; wem dies gelinge, der sei der Träger des echten Rings.

Die Parabel hat zu mehreren Interpretationen geführt:

1. Gott liebt alle drei Religionen gleichermaßen

2. Gott liebt die Religion am meisten, die von allen Menschen angenommen und respektiert wird und die alle Menschen eint. 
3. Der echte Ring kann an seiner Wirkung erkannt werden. Gleiches gelte für die Religionen.

4. Es gehe eigentlich um eine einzige Religion, die sich in nur in drei Religionen unterteilte. Der Richter der Ringparabel stehe für den einen Gott und es gehe darum, die drei Religionen erneut zu einer starken Einheit zu verbinden.

Keine dieser Interpretationen konnte sich jedoch durchsetzen, wie wir immer wieder erfahren können. Dennoch ist Lessings Toleranzappell nach wie vor bedenkenswert.

Friedrich Schiller nennt die neuen Aufgaben des Theaters:

Moralische Anstalt und Schule praktischer Weisheit,

gesellschaftspolitische Anstalt und Instrument der Aufklärung, ästhetische Anstalt.

Charakterisierungen, die bis heute ihre Spuren im deutschen Theater hinterlassen haben

\section{Annäherungen von Theater und Kirche im 20. Jahrhundert}

In unserer heutigen säkularen Kultur haben sich einige Relikte der Tradition des Geistlichen Spiels erhalten. Sie unterscheiden sich aber grundsätzlich durch das Fehlen eines magischen Bewusstseins. Die Passionsspiele in Oberammergau haben mit den rauschhaften Massenveranstaltungen des Spät-Mittelalters überhaupt nichts mehr zu tun. Dass diese Passionsspiele, die auf ein Gelübde aus dem 17.Jahrhundert während der Pestepedemien zurückgehen, diese Spiele alle 10 Jahre mit der ganzen Dorfgemeinschaft zu spielen, da man von der Pest verschont blieb, doch nicht so frei sind, zeigt eine aktuelle Diskussion. Der Regisseur wollte die Aufführung vom Nachmittag, wo die Geißelung und Kreuzigung Jesu nach bilblischer Überlieferung stattgefunden haben soll, auf den Abend verlegen, weil sich in der Dunkelheit die Szenen theatral wirkungsvoller ausleuchten ließen. Das hatte eine heftige Diskussion zur Folge, ob das erlaubt werden könnte. Das theatrale Argument setzte sich doch dann durch. Entsprechend der ästhetischen Tendenz der europäischen Theatergeschichte sind sie künstlerische Veranstaltungen. 
In den Kirchen gab es am Anfang des 20. Jahrhunderts in Folge der Jugendbewegung und Reformpädagogik eine Wiederbelebung des Laienspiels. Man griff auf Mysterienspiele, Totentänze, Volksspiele zurück. Auch liturgisches Interesse prägten die Aufführungen . in denen Nationalgefühl und Glaubenszeugnis einhergingen. Eine Botschaft galt es auszurichten und zu verkündigen. Im diktatorischen, terroristischen Nationalsozialismus überlebte das religiöse Spiel innerhalb der Kirchengemeinden als gottesdienstliches Spiel.

Nach dem 2. Weltkrieg knüpfte das Laienspiel an die Praxis vor 1933 an. Das Verkündigungsspiel lebte fort, obwohl neue Spielformen hinzukamen, weg von der religiösen Diktion unter Verwendung von Formen des damaligen professionellen Theaters. Die Erkenntnisse des christlichen Glaubens sollten neu verstehbar und eine verbesserte Welt exprobt werden. Es entwickelte sich eine Abkehr vom traditionellen Laienspiel hin zum Amateurtheater. Die Veränderungen der Theaterlandschaft in den 60iger, 70iger Jahren wirkten sich auch hier aus. Mit Texten wurde- wenn überhaupt - frei subjektiv und assoziativ umgegangen..Experimentierfreude , Selbstverwirklichung waren wichtige Triebkräfte. Das Verkündigungsspiel alter Provinienz verschied. Angeregt und ermutigt durch die damaligen Theaterbewegungen und den Kreativitätsboom wurde jetzt der persönlichen, subjektiven Konfrontation mit den biblischen Texten, der freien szenischen Improvisation, dem Interaktionsprozess zwischen Spielern und Zuschauern die entscheidende Rolle zugeteilt. Die Fragen wurden auf dem Theater wichtiger als die bekenntnishaften Antworten. Daraus entstand auch eine heute anerkannte Praxis zur Erschließung biblischer Texte und persönlicher christlicher Existenz: das Bibliodrama. Eine gruppeninterne Methode, erfahrungs- und testorientiert mit dem Ziel, eigene Erfahrungen mit Hilfe des Spiels und spielerischer Interaktionen in Kontakt zu bringen mit den Erfahrungen, die in den Geschichten und Personen der Bibel zu finden sind. Eigene Erfahrungen sollen mit fremden Erfahrungen konfrontiert werden, um zu neuen lebendigen Begegnungen zu kommen, aus emotionale Klischees herauszuführen. Es geht um die Entdeckung des befreienden, lebensfreundlichen Potential in den biblischen Texten. Weihnachts- und Krippenspiele von Kindern und Jugendlichen, mehr religionsdidaktische Aufführungen und liturgische Teile des Gottesdienstes leben aber erfolgreich fort.

Im professionellen Theater gab es nach dem II.Weltkrieg (1945) Bemuihungen um ein christliches Theater, mit Stücken von Thornton Wilder oder Reinhold Schneider u.a., die die 
christlichen Werte, die in den Kriegen zu Schaden gekommen waren, neu zu verkünden. Dies blieb aber folgenlos. In den 70iger Jahren wurde dann das kritische Gespräch zwischen Kirche und Theater durch Hochhuths "Stellvertreter" über das Verhalten des Papstes während des Holocaust, entzündet. Die Reformation, der Aufstand gegen die etablierte Kirche, wurde von Forte und Osborne dramatisiert in ihren Stücken über Müntzer und Luther.

In diesen Jahren entstanden auch Theatergruppen, die auf Straßen und Märkten, in Sälen und Kirchen spielten, zum Wohl einer kranken Gesellschaft, durch Therapie und metaphysische Zeremonien. Sie lehnten den Krieg ab und alle lebensfeindlichen Kräfte. Das Bread and Puppet Theatre nahm biblische Geschichten auf, entwickelte mit Puppen und Großfiguren Spiele, die an die symbolischen Handlungen alttestamentlicher Propheten erinnern (Buch der Könige, Schrei des Volkes nach Speisung, Die 14 Stationen des Kreuzes). Rhythmus, Ritual, Körper und Bilder wurden auf dem Theater wieder entdeckt, weniger Stücke als Ereignisse inszeniert. Beim Living theatre entsteht rituelles Theater, das direkt auf das Leben wirken soll. Die Distanz zwischen Zuschauer und Spieler soll aufgehoben werden, eine „unio mystica" soll entstehen. In der Produktion von „Paradise now" z.B. werden die Zuschauer improvisierend einbezogen und lassen sich in einem Akt extatischer Befreiung mitreißen, dem Stille, Meditation und Gesang folgen.

Wenn die Schauspieler des Living Theatre die Exerzitien in einem Militärgefängnis auf die Bühne brachten, indem sie sich dieselben körperlichen Anstrengungen zumuteten, wie die Rekruten, dann geht es nicht mehr um repräsentative Darstellung, sondern um den Vollzug von Handlungen, nahe einer rituellen Praxis. Auf der Suche nach der Wirksamkeit des Theaters entdecken sie die Wirksamkeit des Rituals. Sie schaffen Gemeinschaftserlebnisse, die keine Zweiteilung in Zuschauer und Schauspieler mehr vertragen. Das Publikum muss zum Mitspieler werden und seine ästhetische Distanz aufgeben. Gerade wenn es um grundlegende existentielle Fragen geht, liegt das nahe.

\section{Nene Begegnungen von Theater und Religion heute}

Auf den deutschen Bühnen war in den letzten Spielzeiten zu beobachten, dass vermehrt die Bibel, die Zehn Gebote, das Thema Glauben etc. als Vorlagen zu Inszenierungen dienten. Der Glaube und seine Texte finden als Ethik und als seelische Befindlichkeit ihren Ausdruck in den darstellenden Künsten. Religiöse Erfahrungen und religiöses Wissen werden lebendig, auf freiwillige und undogmatische Art.

Zeigt sich darin die Sehnsucht nach Spiritualität, der es nicht nur um Selbstverwirklichung geht, sondern auch um Kritik an unseren Lebensgestaltungen, die ohne Religiosität und 
Spiritualität auszukommen versuchen? Lässt der Empirismus der Moderne unser Bedürfnis nach Transzendenz unbefriedigt? Sind Gefuihle und Emotionen total abstrakt geworden ? Zerfallen soziale Bindungen, nimmt sich das Ich zum alleinigen Inhalt und erklärt sich zum einzigen Maßstab? Ist die Aufklärung am Ende und an ihrer Stelle das goldene Kalb getreten, wie Max Frisch schon vor Jahrzehnten feststellte? Das Theater engagiert sich offenbar stellvertretend für die Gesellschaft für die Suche nach Sinn, Orientierung, nach Werten, angesichts unserer Alltagsprobleme und ungelösten gesellschaftlichen Fragen. Sind wir auf der Suche im Westen nach Antworten auf Fragen, wie "Was hat unsere Gesellschaft fanatisierten Glaubenskriegern entgegenzusetzen? Genügen Toleranz und Multikulturalismus? Gewinnen wir nicht zunehmend den Eindruck, dass durch den Verlust aller Utopien und ideologischer Sinnstiftungsangebote die Suche nach metaphysischen Werten wieder wächst?"

Es scheint fast eine therapeutische Aufgabe.

Das Theater scheint sich hier auch besonders zu eignen, denn seine Ästhetik hat es immer mit sinnlicher Wahrnehmung zu tun. Sie macht Handlungsräume, Motive, Prozesse anschaulich und kann zu größerer Bewusstheit beitragen. Ästhetik kann so eine notwendige Voraussetzung für ethisches Handeln, moralisches Urteilen schaffen. Die Ästhetik des Theaters bietet Probierund Experimentierfelder für Lebensstile und -formen an und zur Auseinandersetzung mit eingeschliffenen Gewohnheiten. Es kann nicht mehr nur darum gehen, heute die düsteren und absurden Dimensionen des menschlichen Zustands zu beleuchten und die Komplexität der Personen und ihrer Handlungen nachzuzeichnen, sondern die empirische weltliche Dimension soll mit transzendenten Ansprüchen überschritten werden. Da kann man auch nicht einfach zum Bekenntnis des bewährten Glaubens zurückkehren. Vielmehr will man neue Kontexte und Realitäten entdecken und vertiefte Fragen an die menschliche Existenz stellen.

Fragen und Hinterfragen ist ja ein Kennzeichen des Theaters. Theater kann den produktiven Kreislauf von Frage und Antwort in Gang halten, Verwerfen und neu suchen, Finden und Zweifeln. Theater hat da eine verblüffende Kraft an unsere Grundfragen heranzukommen und so auch Religion lebendig zu halten.

Insbesondere drei Wege werden deutlich, wie Theater heute sich den religiösen und spirituellen Dimensionen nähert: 
1. Autoren und Theaterleute greifen zurück auf Texte des Alten und Neuen Testaments der Bibel. Sie entdecken in diesen Texten auch brisante politische Aktualität.

Der russische Regisseur Anatolij Wassiljew gestaltete in Moskau „Die Klagelieder des Jeremias“ - über die Zerstörung Jerusalems, mit der Frage nach Schuld und Verantwortung, choreographisch mit liturgischen Gesängen und orthodoxer Kirchenmusik. Durch den gleichzeitig stattfindenden Tschetschenienkrieg erfuhr die Aufführung eine brisante Aktualität.

Romeo Castellucci schuf in Italien ein großes Triptychon "Genesis - from Museum of Sleep“. Er bringt das Chaos vor der Schöpfung, Auschwitz und den Brudermord Kains in eine Verbindung. Die Inszenierung beginnt mit der Rezitation aus der Thora in Althebräisch. Die Worte wirken wie Klänge.Aus der Schöpfung folgt nach Castelluccis Vision in der Entwicklung der Menschheit die perfekte Vernichtung. Kinder spielen Auschwitz. Das älteste Kind fährt auf einer Spielzeugeisenbahn über die Bühne, gekleidet in weißem Frack, mit gelbem Judenstern. Die dröhnenden Zuggeräusche weisen auf das Konzentrationslager hin. Im dritten Bild wird dann der Brudermord gezeigt, mit Kain als erschrockenem Mörder, der vergeblich versucht die Tat rückgängig zu machen.

\section{Auf der Suche nach den Ursprüingen des Theaters.}

Hier arbeitet das Theater gleichsam theaterarchäologisch, sucht nach seinen Wurzeln und stöBt dabei immer auf rituelle, kultische, religiöse Ursprünge. Ob es sich mit mittelalterlichen Mysterienspielen, heidnisch antiken Ritualen oder dem Schamanismus beschäftigt, bei den Recherchen stößt man auf "Geysire"( so Staniewski), die Religiöses an die Oberfläche schleudern.

Der polnische Regisseur Wlodzimierz Staniewski aus Gardzienice gräbt tief in der Geschichte. In dem Stück „Metamorphosen“ nach Texten von Apuleius über die Begegnung des Heidentums mit dem Christentum untersucht er antike Gesangstechniken und entwickelt daraus eine Dynamik des Körperausdrucks und ein Ritual.

Auch Jerzy Grotowski experimentierte in seinem „Theater der Quellen“ mit Gesängen aus unterschiedlichen Kulturen und erforschte die Wirkungen der Schwingungen auf Körper und Geist. In fast allen Kulturen sind Schwingungsgesänge mit ritueller Praxis verbunden. Es geht um den Vollzug eines Rituals. Auch andere Regisseure suchen nach alten Ritualformen, die aus der Antike, dem Schamanismus, Voodoo, Mysterienspielen kommen, wie z.B. Peter Sellars (USA), Lin-Hwaimin (Taiwan), Ga Sola (Vietnam). 
3. Bezogen auf Lebens- und Sinnprobleme, bei der Konfrontation mit der Erfahrung von Endlichkeit werden religiöse Fragen berührt. Theater, das mit der Auflösung von Gewissheiten zu tun hat, mit dem Tod konfrontiert, Grenzerfahrungen darstellt, weckt religiöse Erfahrungen, und kann bis zum Rausch und zur Extase führen. Der Schauspieler wird zum Performer.

In einer Performance „Die Lippen des heiligen Thomas“ zerbrach Marina Abramovicz ein Kristallglas und ritzte sich einen Stern in die Bauchhaut, peitschte sich den Rücken und legte sich entkleidet auf ein Kreuz aus Eisblöcken. Nach 30 Minuten griff das Publikum ein und beendete die Performance. Abramovicz sagte:" Kunst machen bedeutet fragen. Nach dem Tod, nach dem Schmerz." Diese Grenzerfahrungen will sie gemeinsam mit den Zuschauern machen. Sie holt sie in die Gegenwart ihrer Aktionen.

Trotz der vielfach im Christentum zu beobachtenden Leibfeindlichkeit, ist aber auch zu registrieren:

In vielen heiligen Texten, die über Tod und Leben reflektieren, wird über Körperlichkeit, Leiblichkeit, Fleischeslust, bis hin zu ekstatischer Hingabe gesprochen. Das Alte Testament hat sogar ein ganzes Buch darüber, das Hohelied, voller Liebeslyrik. Gottesliebe gerät nämlich in Gefahr, abstrakt und unsinnlich $\mathrm{zu}$ werden, wenn keine Erfahrungen erotischer Fantasien erfahren werden. Zwischen Gottesliebe und Liebeserfahrungen gibt es Zusammenhänge. Liebe ist riskant und immer bedroht von Verletzung und Verwundung. Der grauenhaft geschundene Leib des gekreuzigten Jesus Christus, der Christus am Kreuz, steht im Zentrum der christlichen Symbolik. In fast allen Religionen wollen Menschen ein neues Verhältnis zu ihrem Körper finden, um dem Göttlichen gerechter zu werden. Fasten, Verzicht, sowie sexuelle Askese gehören dazu. Auch die Selbstgeißelung ist in vielen Religionen bekannt. Durch Schmerz soll die Intensität der körperlichen Selbstwahrnehmung gesteigert werden, eine imitatio der Leiden Jesu Christi soll erreicht werden. Der Körper wird zum Medium der Heilssuche.

In den 60iger, 70er Jahren vollzieht sich eine "performative Wende" in der kulturellen Szene.

Im der gegenwärtigen Inszenierungspraxis ist $\mathrm{zu}$ beobachten, dass das Theater seinen Kunstcharakter abstreifen will, um dem Leben nahe zu kommen. Nicht die Erzählung, sondern der Rhythmus, das Ereignis bestimmen die Form und verweisen auf Intensität oder gar Extase. .Entsprechend den Praktiken der Performance-Kunst werden wirkliche Handlungen anstelle des schauspielerischen Als-ob auf die Bühne gebracht. Nicht Darstellen, sondern Vollziehen wird zum Prinzip, Artauds Forderung folgend, „dass der Schauspieler nicht spielt, sondern mit seinem ganzen Leib, mit seiner Existenz verkörpert, was sonst nur gezeigt wird." Nicht Sinn 
bringen Aufführungen hervor, sondern unmittelbar präsente Materialität und Körperlichkeit. Es geht um ein Zusammenführen von Sein und Bedeutung, von Zeichen und Bezeichnetem. Eine Erfahrung, die man auch mystisch nennen könnte. Akteure und Zuschauer sind in einer Situation verbunden und machen gemeinsame unmittelbare Erfahrungen. Es wird die Erfahrung von Präsenz erzeugt, das Bewusstsein von Gegenwärtigkeit. Merkmale von Performance, die dem Ritual sehr verwandt sind. Eine neue, sehr alte ästhetische Sensibilität hat sich hier entwickelt, die ein stetiges produktives Feed-back des Zuschauers auf die Performanz der Akteure hervorruft.

Die Parodie, die Komik, das Närrische werden auch in der Begegnung mit der

Religion wiederentdeckt .Christus als Clown hat tiefe historische Wurzeln. Eine der ältesten Darstellungen von Christus in der Kunst zeigt eine gekreuzigte menschliche Gestalt mit dem Kopf eines Esels. Ist es eine brutale Parodie oder ein Geheimzeichen? Vielleicht sahen aber auch die Katakombenchristen darin ein Symbol ihrer absurden Situation. Sie wussten, dass sie „Narren in Christo“ waren, behaupteten aber, dass die Narrheit Gottes weiser sei als die Weisheit der Menschen. Christus hat Züge des Clowns. Er verhöhnt vorgegebene Autoritäten, spottet über Regeln und wird zum Schluss wie eine Spottkarikatur in königliche Gewänder zur Kreuzigung gekleidet. Der Clown repräsentiert immer den Anderen, der leidet und gebrochen ist, aber nie die Hoffnung verliert. Der Clown steht immer auf der Seite des Lebens und des Schöpferischen. Aus Sorge um die Welt tritt er stets gegen bestehende zerstörende Ordnungen an. Das gilt auch für das Religiöse. Der italienische Autor und Theatermann Dario Fo nimmt diese Spur wieder auf, wenn er die biblischen Geschichten aus der Perspektive des Volkes, in der Tradition des reisenden Spielmanns erzählt. Er befreit sich und sein Publikum von der traditionellen, offiziellen Version der Christusgeschichte. Er will Christus als den demütigen Sieger der Unterdrückten zurückgewinnen, der sich nie mit dem Prunk und dem Reichtum der Kirche abfinden würde. Seine Bibelgeschichten werden zu Satiren auf die Ausbeutung der Religion zu Herrschaftszwecken. Auch andere deutsche Autoren entdecken den Narren wieder: Tankred Dorst sieht in seinem Stück „Die Geschichte der Pfeile“ die Narren als „verlängerte Finger Gottes“. Peter Handke weist in seinem Stück „Die Stunde, da wir nichts von einander wussten" dem Narren eine zentrale Rolle zu.

Der Clown, der Narr erlauben uns, die Welt mit anderen Augen zu sehen. Damit ist eine grundlegende Aufgabe des Theaters benannt: es soll nicht das Leben, wie wir es kennen, zeigen, sondern uns Erfahrungen machen lassen, die es uns erlauben, darüber hinaus zu gelangen, andere Realitäten und Kontexte zu entdecken. Das fordert dann auch den Dialog 
zwischen Theater und Religion heraus.

\section{IV. Ästhetik und Religiöse Erfahrung / Inszenierung Sakraler Räume}

Nicht nur vor Kirchenportalen, sondern auch in den Kirchen selber wird heute wieder Theater gespielt. Aber auch dabei geht es nicht darum, Kunst wieder zum Kult zu machen, aus dem sie sich ja befreit hat. Es geht auch nicht darum, Kult (Religion) zur Kunst zu machen. Die gegenseitige Autonomie muss beachtet werden: es geht nicht um religiöses Theater, sondern um Theater im Raum der Kirche, wo sich Kirche und Theater in der ganzen Breite ihrer Wirklichkeit begegnen, sich nicht gegenseitig einverleiben, aber einen Dialog führen. Denn sie haben sich viel zu erzählen.

Ein Kirchenraum ist ein Ort, wo ich Gottes Wort erwarte, erlebe und erinnere. Er ist Erinnerungs- und Selbstbesinnungsraum. In ihm ist die Erfahrungsgeschichte des Glaubens überliefert und die Lebensübergänge werden rituell gestaltet, Taufe, Heirat, Tod. Von einer Lebenssituation zur anderen, aus dem Alltag ins Nicht-Alltägliche, von der Tradition zur Gegenwart, von der Gegenwart zur erhofften Zukunft. Mit dem Eintritt in eine Kirche überschreite ich eine Schwelle in einen anderen „Sinnbezirk“. Es ist der Ort, an dem der Alltag unterbrochen wird, transzendiert wird.

Auch als Spielraum des Theaters verbleibt dieser Raum im Kontinuum der religiösen Wirklichkeit. Die Kunst erhält Konnotationen, wie sonst nie. Zwei Sinnebenen begegnen sich. .Beim Zusammentreffen der Konzepte von Raum als religiöse Wirklichkeit mit der ästhetischen Wirklichkeit des Theaters machen Zuschauer die Erfahrung von Differenzen, auch von Bruch. Das ist das Kreative daran, gewohnte Wahrnehmungsmuster - auch religiöse - werden in Frage gestellt, Widersprüche aufgedeckt, Reibungen entwickeln sich. Es können sich dabei neue Bedeutungsräume öffnen. Der Dialog kann beginnen. Manche Menschen sind empfänglich für diese neuen Erfahrungen und öffnen sich für das „Fremde“, während andere sich entziehen oder sogar massiv zur Wehr setzen. Die Erwartungen nach Sinnvergewisserung und Heilung, nach Ruhe und Geborgenheit können zusammenprallen mit Verletzungen und Demontage von Erfahrungsmustern und vorgegebenen Wahrnehmungsweisen. Kunst hat eine anarchische Dimension, sie entgrenzt und befreit. Sie rennt gegen Dogmen an und gegen Herrschaftsansprïche.

Weder der Kult noch das Theater dürfen aber Räume so erschließen, dass kein Raum für Deutungen bei uns bleibt. Sie müssen vielmehr Freiräume schaffen, die von uns gefüllt werden können. Bei uns müssen Deutungsaktivitäten entstehen können. Es muss uns etwas angehen. 
Wie schwierig aber der Dialog zwischen Theater und Religion werden kann, gerade wenn Rituale in dem ritualnahen Raum der Kirche vollzogen werden, zeigt folgendes Beispiel:

1987 inszenierte der österreichische Theatermann George Tabori bei den Salzburger Festspielen das Oratorium "Das Buch der sieben Siegel" von Franz Schmidt in der Kollegienkirche. Die Inszenierung rief nicht nur kontroverse Reaktionen hervor, sondern einen Skandal, der zur Absetzung der Inszenierung führte und nur noch eine konzertante Darstellung zuließ.

Das Oratorium beschreibt die Offenbarungen des Johannes. Das Buch mit den sieben Siegeln kann nur durch das Lamm geöffnet werden. Die Öffnung eines Siegels bringt jeweils Naturkatastrophen, Krieg, Leid, Tod und Vernichtung der Menschheit hervor. Nach dem Sieg aber des Erzengels Michael über das Böse verkünden die sieben Posaunen die Endzeit. Gott beendet die Plagen und es entsteht ein neuer Himmel und eine neue Erde. Tabori interessierte die Vergegenwärtigung dieser existentiellen Ängste und Hoffnungen des Johannes - wie können wir das heute erleben. Er will unsere Apokalypse finden und geht assoziativ vor. Der

Kirchenraum wird zum Bewegungs- und Schauraum, die Grenzen zwischen Akteuren und Zuschauer werden durchlässig, die ästhetische Distanz wird verringert.

Auf einem Gerüst im Raum sind die Akteure, in festlicher Garderobe, und nehmen Kontakt zu herumhängenden Puppen auf, der immer aggressiver wird. Gliedmaßen, Körperteile fallen herunter und die Aggression überträgt sich auf die Menschen untereinander. Eine körperbetonte Aktion, Sexualität wird zerstörerisch, sadistische Rituale entstehen. Zerstörung, Krieg im zwischenmenschlichen Bereich, unterbrochen immer wieder vom Small-Talk, der eine Fassade von heiler Welt dazwischen zelebriert. Beim großen Erdbeben dann verkrallen sich die Leiber angstvoll. Nach der Ankündigung der Endzeit mit dem Frieden fallen die Akteure über einen jungen Mann her, der ihnen Brot reichen wollte, zerfleischen ihn und essen sein Fleisch. Ein Opferritual, die Gewalt der Gemeinschaft schlägt um in Gewalt der Gemeinschaft auf einen Einzelnen. Er wird als Verursacher der Krise getötet und später zum Heilsbringer gemacht. Das erinnert an den Opfertod Christi und das Abendmahl. Das ist gerade in einer katholischen Kirche eine brisante Zuspitzung. Der geopferte junge Mann erhebt sich schließlich und steigt auf das Gerüst. Soll er der Christus sein, der neue Adam, Johannes oder vielleicht der Teufel? Die Deutung bleibt offen, ein weiter Deutungs- und Interpretationsspielraum öffnet sich für den, der dazu bereit ist. Eine einheitliche Sichtweise und eindeutige Senngebung werden verweigert. Die Empörung aber schlug hoch, die unterschiedlichen Vorstellungen prallten aufeinander, 
Vorwürfe von pornographischer Darstellung folgten. Eine produktive Auseinandersetzung, ein Dialog fand nicht statt.

\section{Ausblick}

Die Gesellschaften in Europa und natürlich auch in Deutschland haben sich im Zuge der Globalisierung und weltweiten Migrationsbewegung besonders in den letzten 50 Jahren gewandelt. Sie sind multiethnisch und interkulturell geworden. Deutschland hat inzwischen über 19 Millionen Einwohner mit Migrationshintergrund. Die stärkste Gruppe kommt aus der Türkei und bekennt sich zum Islam. Die Exklusivität des Christentums kann nicht länger behauptet werden. Der Islam ist nicht mehr zu übersehen. Wie geht nun das Theater mit dieser Interkulturalität, der Interreligiösität in Deutschland um? Noch hat das Theater kaum darauf reagiert.

Eine Ausnahme bildet ein Autor, der als Kind aus der Türkei nach Deutschland kam, Feridun Zaimoglu. Sein vielfach nachgespieltes Stück „Schwarze Jungfrauen“ wurde von Kritikem zum besten deutschsprachigen Stück gewählt und erwies sich als Publikumsmagnet. Beim deutschen Publikum, denn Migranten sieht man kaum im Theater, obwohl die Schauspielensembles zunehmend interkulturell besetzt sind. Die Aufführungen des Stückes zerstörten in den Köpfen der Deutschen die Bilder von den braven Frauen mit Kopftüchern, die nur zu Hause sitzen und auf die Kinder aufpassen und nichts von der Welt mitbekommen. Die Muslima sprechen auf der Bühne von der Zerrissenheit der Kulturen, in denen sie in Deutschland leben, sie wehren sich dagegen, misstrauisch beäugt $\mathrm{zu}$ werden und sich für ihre Religionszugehörigkeit immer verteidigen zu müssen. Sie äußern sich voller Wut und mit Stolz, aber auch mit vielen Widersprüchen.

Feridun Zaimoglu hatte mit jungen Muslima in Deutschland Interviews geführt und ihre Lebensbeichten in Monologe gefasst. Die Inhalte hatte er belassen, sie aber in seine Sprache umgesetzt, die nicht schamhaft oder verschleiert daherkommt, sondern im Gegenteil direkt, vulgär und geradezu obszön. Die jungen Frauen sind sich ihres Glaubens sicher und äußern sich radikal und politisch provokativ, wenn eine es z.B. gut findet, dass die Twin-towers eingeebnet wurden oder die andere Osama bin Laden liebt. Hass, Aggressionen, Leidenschaft und Sehnsucht nach Liebe drücken sie in rotzigen Predigten aus, sie sprechen offen von „Ficks“ und „schwellenden Brüsten“. Eine sagt: „Ich bete fünf mal am Tag. Ich faste im Ramadan. Ich bin überzeugte Muslima. Aber ich ficke immer noch, weil ich weiß, es schadet nicht meinem Glauben.“ 
Der Autor, Feridun Zaimoglu, meint: "Das Verblüffende ist, dass muslimische Frauen im Vergleich zur christlichen Tradition ein eher schamloses Verhältnis zu ihren Körpern haben selbst wenn sie voll verschleiert sind. Im Islam ist Leibfeindlichkeit eine Todsünde, mit Zölibat kommt man geradewegs in die Hölle." Mit der Verbindung von Sex und Islam mutet uns Zaimoglu einiges zu. Er sagt zu seinem semi-dokumentarischen Stück: „Ich habe nun mal eine dekadente Neugier auf alles, was gegen die Aufklärung gebürstet ist. Mir geht's nicht um Verständnis, Toleranz oder Einfühlung. Auch nicht ums Anzapfen besonders abgefahrener Haltungen. Sondern um das Sichtbar-Machen dieser Leute ohne moralische Wertung. Das Böse kann auch ganz gut schillern."

Der Dialog mit den Religionen im Theater - nicht harmonisierend, harmonisch, sondern mit allen Differenzen, in seinen Polyfonien - lässt noch spannende, spannungsreiche Erfahrungen erwarten und hoffentlich viele Erkenntnisse, die unserem Zusammenleben hilfreich sind. 